\title{
Assessment of biological and agronomic diversity of seven durum wheat varieties cultivated in the Northeastern region of Algeria
}

\author{
NABIL BOUDERSA ${ }^{1, \vartheta}$, GHANIA CHAIB $^{1}$, AICHA ATOUI ${ }^{1}$, RADIA CHERFIA ${ }^{2}$, HANANE BOUDERBANE ${ }^{1}$, \\ LEILA BOUDOUR ${ }^{1}$ \\ ${ }^{1}$ Laboratory of the Development and Valorization of Plant Genetic Resources, Department of Biology and Plant Ecology, Frères Mentouri University. \\ Constantine1, Route de Ain El Bey, Constantine 25017, Algeria. Tel. +213-671977482, `email: nabil.boudersa@ student.umc.edu.dz \\ ${ }^{2}$ Laboratory of Mycology, Biotechnology and Microbial Activity, Department of Applied Biology, Faculty of Nature and Life Sciences, Frères Mentouri \\ University. Constantine1, BP, 325 Route de Ain El Bey, Constantine 25017, Algeria
}

Manuscript received: 30 November 2020. Revision accepted: 25 January 2021.

\begin{abstract}
Boudersa N, Chaib G, Atoui A, Cherfia R, Bouderbane H, Boudour L. 2021. Assessment of biological and agronomic diversity of seven durum wheat varieties cultivated in the Northeastern region of Algeria. Biodiversitas 22: 1025-1036. The present work was carried out during the 2017/2018 agricultural season, at the experimental station of the 'Institut Technique des Grandes Cultures' (ITGC) - El Khroub, Constantine, Algeria. The main objective of this study was the evaluation and the characterization of seven varieties of durum wheat (Triticum durum Desf.) in terms of their behavior and yield. For these reasons, several phenological, morpho-physiological, and biochemical traits, as well as the yield with its components were studied. The obtained results showed a significant variety effect, in particular, for the variables corresponding to the production and to the tolerance. The analysis of the correlation coefficients indicated that the number of spikes per $\mathrm{m}^{2}$, the number of grains spike ${ }^{-1}$, and the rate of chlorophyll pigments in the leaves were the most related characteristics to grain yield. Indirect selection for breeding productivity through these traits could prove to be effective. Besides, it revealed that tall varieties displayed better resistance to possible hazards; had high relative water content (RWC), accumulated more soluble sugars and proline, as well as, they showed a low level of Malondialdehyde (MDA) compared to other varieties. In addition, this study allowed us to determine many relationships between the studied parameters, that can make a contribution in both the productivity and the adaptation improvement programs of the durum wheat.
\end{abstract}

Keywords: Characterization, correlation, diversity, productivity and adaptability, Triticum durum

\section{INTRODUCTION}

Triticum durum Desf. is one of the most essential cereals that are cultivated worldwide on almost 17 million hectares (ha), with a global production of 38.1 million tonnes in 2019 (Xynias et al. 2020). In Algeria, durum wheat is the first cultivated cereal; it occupies $45 \%$ of the area designated for cereals, or 1.6 Mha (ONFA 2017). However, its production is still insignificant, it covers only 20 to $25 \%$ of the needs of an increasingly growing population, and the rest being imported (Chehili et al. 2017). This low production is often explained by the fact that the majority of the area sown to durum wheat is located on the high plains, where the rainfall and the temperatures are subjected to large intra and inter-annual variations, often combined with frequent spring frosts and the appearance of sirocco at the grain filling stage; which seriously affect the yields (Benniou et al. 2018). Indeed, this situation can only be unblocked by a real and an effective increase in yields through the application of better management of both adapted technical pathways (soil preparation, date and dose of sowing, irrigation, fertilization, weed control, and disease control), and genetic improvement allowing to create adapted varieties to environmental conditions of cultivation.

The goal of genetic improvement in wheat has always been to increase productivity. Whereby, the success of this strategy is linked to the existence of favorable environmental conditions, which allow the expression of the different factors of the yield (Ghennai et al. 2017). For this reason, the study and the characterization of genetic resources to create new varieties with good quality, high yield, adapted to climatic variations, and resistance to diseases are essential (Amallah et al. 2016). Besides, these steps also make it possible to estimate the existing diversity in the studied material, and they are considered as a starting point for their use in breeding programs (Khennaoui 2018). Thus, this research requires studying, identifying, and verifying the phenological, morpho-physiological, and biochemical characteristics related to the yield. Therefore, a good understanding of all of these aspects during the life cycle of the plant and a well comprehension of the main links between the grain yield and these components can be useful in the identification and the selection of the interest traits. Indeed, several agricultural studies have confirmed that this information is used to guide the selection process in order to improve the characteristics capable of obtaining better performance (Aghaee et al. 2010; Zarkti et al. 2012; Sahri et al. 2014).

The current study had two main objectives: (i) Evaluation of the variability of seven varieties of durum wheat, using measurements of agro-morpho-physiological and biochemical characters. (ii) Analyzing and highlighting the different links recorded between the studied parameters 
in order to improve our knowledge about the extraction of the most discriminating and important traits that may be useful for the classification and the characterization of durum wheat varieties. This study, also, allowed us to identify the most interesting and relevant varieties that would largely be behind the choice of adapted genotypes to the unfortunate conditions.

\section{MATERIALS AND METHODS}

\section{Plant material}

This study has focused on seven varieties of durum wheat (Triticum durum Desf.) mostly cultivated in the region of northeastern Algeria. The grains were supplied by the 'Institut Technique des Grandes Cultures' (ITGC) of Constantine, Algeria. The name, the pedigree, and the origin of the varieties are shown in Table 1.

\section{Location of the experiment}

The experiment was conducted on the ITGC site of El Khroub, Constantine, Algeria at an altitude of $640 \mathrm{~m}$, a latitude of $36.25^{\circ}$ North and a longitude of $6.67^{\circ}$ East (Figure 1). The site soil has a slimy-clayey texture, with a dry condition, a depth of $120 \mathrm{~cm}$, and a flat topography. The bioclimatic stage of the site is semi-arid, characterized by a Mediterranean climate and an average annual rainfall of $450 \mathrm{~mm}$ over 25 years.

\section{Physicochemical characteristics of the soil in the experimental area}

Soil analysis was regularly carried out by the ITGC laboratory. The results are shown in Table 2.

\section{Test setting up}

The test was carried out during the 2017/2018 agricultural campaign. The sowing was carried out on
January $03^{\text {rd }}, 2018$. A manual sowing was carried out at a regular depth of $4 \pm 1 \mathrm{~cm}$ by distributing the grains in a regular manner along parallels lines.

The adopted experimental device is a simple device, which consists in distributing the plots CÔTE to CÔTE. Each five meters long by 1.2 meters wide and comprising six lines $20 \mathrm{~cm}$ apart from each other; i.e. an area of $6 \mathrm{~m}^{2}$, the distance between plots is $50 \mathrm{~cm}$. Each elementary plot receives a unique treatment at a density of 250 seeds $/ \mathrm{m}^{2}$ (Table 3).

\section{Climatic characteristics of the experimental site}

The observed characteristics in the region are notably the rainfall and the temperature (Table 4). These two factors have an important effect on the development of cereals. According to Table 4, the cumulative rainfall was generally good with an annual cumulative rainfall of 550 $\mathrm{mm}$. This year was characterized by fairly rainy autumn which allows adequate preparation of the seedbeds. The winter period was marked by relatively average rainfall, which allowed a good start to the crop. The spring was fairly well moist with a suitable beneficial distribution for the development and the formation of crop yield components. Temperatures were mild during this campaign.

Table 1. Name, pedigree, and origin of the used varieties

\begin{tabular}{|c|c|c|}
\hline Variety & Pedigree & Origin \\
\hline Waha & Plc/Ruff//Gta's/3/Rolette CM 17904 & $\begin{array}{l}\text { Syria, } \\
\text { Algeria }\end{array}$ \\
\hline Cirta & $\begin{array}{l}\text { KB214-0KB-20KB-OKB-OKB-1KB- } \\
\text { OKB }\end{array}$ & Algeria \\
\hline Wahbi & KB86022-1KB0KB-2KB-2КВ0КB & Algeria \\
\hline Bousselem & Heider/Martes/Huevos d'Oro. ICD-414 & Algeria \\
\hline Semito & Capeiti8/Valvona & Italy \\
\hline GTA dur & $\begin{array}{l}\text { Crane/4/PolonicumPI185309//T.glutin } \\
\text { en/2* Tc60/3/Gll }\end{array}$ & $\begin{array}{l}\text { Mexico, } \\
\text { Algeria }\end{array}$ \\
\hline Vitron & Turkey77/3/Jori/Anhinga//Flamingo & Spain \\
\hline
\end{tabular}

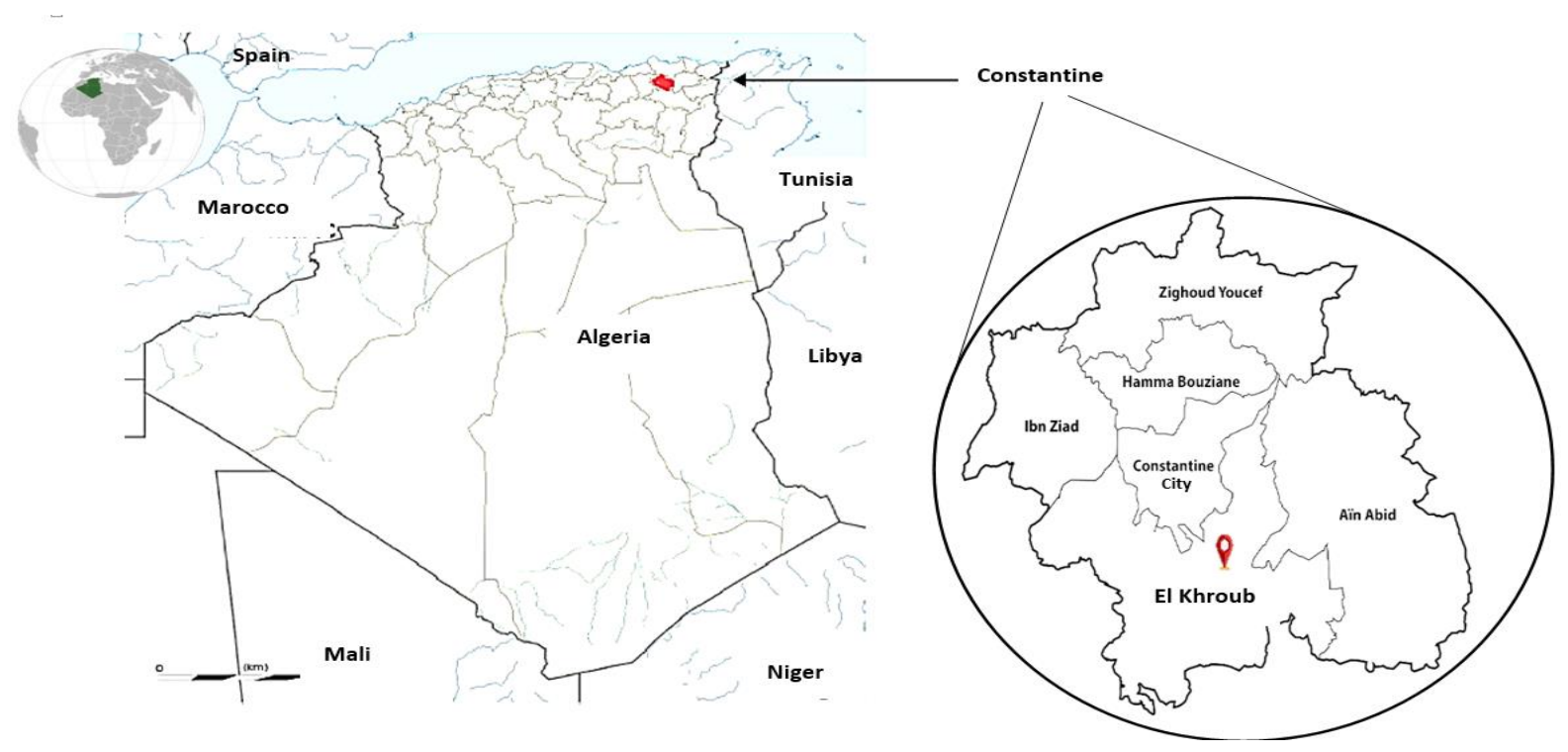

Figure 1. Geographical location of the study area 
Table 2. Physicochemical characteristics of the soil

\begin{tabular}{lccc}
\hline \multicolumn{1}{c}{ Depth (cm) } & $\mathbf{0 - 3 0}$ & $\mathbf{3 0 - 6 0}$ & $\mathbf{6 0 - 9 0}$ \\
\hline Clay (\%) & 55 & 44 & 60 \\
Fine silt (\%) & 29 & 3 & 6 \\
Coarse silt (\%) & 3 & 3 & 4 \\
Fine sand (\%) & 11 & 11 & 18 \\
Coarse sand (\%) & 3 & 3 & 13 \\
Organic matter (\%) & 1.49 & 1.45 & 1.37 \\
pH & 7.6 & 7.6 & 7.9 \\
Electrical conductivity (mS/cm) & 0.5 & 1.7 & 0.6 \\
Real density (g/cm3) & 2.2 & 2.2 & 2.2 \\
\hline
\end{tabular}

Table 3. Main characteristics of the test during the campaign

\begin{tabular}{|c|c|}
\hline Characteristics of the tests & Dates, tools, and used doses \\
\hline Previous cultivation & - Lentil cultivation. \\
\hline Plowing & $\begin{array}{l}\text { - Carried out at the end of } \\
\text { September at a depth of } 35 \mathrm{~cm} \\
\text { with a plowshare. }\end{array}$ \\
\hline Cross-crossing & $\begin{array}{l}\text { - } 1^{\text {st }} \text { passway October } 15^{\text {th }} \text {, } \\
2017,2^{\text {nd }} \text { passway October } \\
22^{\text {nd }}, 2017 \text { with a Cover crop. }\end{array}$ \\
\hline In-depth fertilization & $\begin{array}{l}\text { - } 100 \mathrm{~kg} \mathrm{ha}^{-1} \text { of MAP }(12 \% \mathrm{~N} \text {, } \\
52 \% \mathrm{P}) \text { on } 21 / 11 / 2017 \text { and the } \\
3^{\text {rd }} \text { Cover crop pass way on } \\
12 / 11 / 2017 \text {. }\end{array}$ \\
\hline Installation date of the sowing & - On 03/01/2018. \\
\hline Seeding rate (Dose) & - $\quad 250$ seeds $/ \mathrm{m}^{2}$ \\
\hline Nitrogen fertilization & $\begin{array}{l}\text { - } 1^{\text {st dose: Urea } 46 \%} \text { dose } \\
0.7 \mathrm{Qt} / \mathrm{ha} \text { on } 02 / 28 / 2018 \text {. } \\
\text { - } 2^{\text {nd }} \text { dose: Urea } 46 \% \text { dose } \\
0.7 \mathrm{Qt} / \mathrm{ha} \text { on } 04 / 04 / 2018 .\end{array}$ \\
\hline Chemical weed control & $\begin{array}{l}\text { - Zoom (anti dicotyledon) and } \\
\text { Akopik (anti-Gramineae) on } \\
\text { 03/05/2018; } \\
\text { - Dose : } 0.25 \mathrm{~L} \mathrm{ha}^{-1} \text { Akopik + } \\
120 \mathrm{~g} \mathrm{ha}^{-1} \mathrm{zoom}^{-}\end{array}$ \\
\hline
\end{tabular}

\section{Measured parameters}

Several agro-morphological, physiological and biochemical parameters were evaluated: the duration of heading $(\mathrm{DH})$ expressed in days from the sowing to the stage of the appearance of the outlines of the spikes. To determine the period of heading, it should be mentioned the date when $50 \%$ of the spikes of the elementary plot emerged from the sheath of the last leaf. The height of the plant $(\mathrm{HP}, \mathrm{cm})$, the area of flag leaf $\left(\mathrm{AFL}, \mathrm{cm}^{2}\right)$, the length of the spike (LS, cm), beards not included, the length of the spike peduncle (LSP, cm), the length of beards (LB, cm), the number of herbaceous tillers (Nb HT), the number of spike tillers ( $\mathrm{Nb} \mathrm{ST}$ ), the grain yield $\left(\mathrm{GY}, \mathrm{t} \mathrm{ha}^{-1}\right)$; and these components including the number of spikes per square meter $\left(\mathrm{Nb} \mathrm{S} / \mathrm{m}^{2}\right)$, the number of grains per spike $(\mathrm{Nb} \mathrm{G/S})$ and the weight of thousand grains (WTG, g). The relative water content (RWC, \%) was determined by the method of Barrs (1968), the determination of chlorophyllian and carotenoid pigments Chl (a), Chl (b), Chl (t), Car ( $\mu$ g.ml ${ }^{-}$ $1 / \mathrm{FM})$ was established according to the method of Lichtenthaler (1987). The determination of proline (Pro, $\mathrm{mg} \mathrm{g}^{-1} \mathrm{FM}$ ) was carried out according to Troll and Lindsey (1955), the determination of soluble sugars (Ss, $\mathrm{mg} \mathrm{g}^{-1} \mathrm{FM}$ ) was performed by the method of (Dubois et al. 1956), and the determination of malondialdehyde (MDA, nmol $\mathrm{g}^{-1}$ FM) was realized according to the method of (Ksouri et al. 2007).

\section{Data processing}

The obtained results were analyzed using the statistical program SPSS v.25. Statistical treatments included the correlations, the analysis of variance, the principal component analysis (PCA), as well as the ascending hierarchical classification (AHC).

\section{RESULTS AND DISCUSSION}

\section{Results analysis}

In light of the results presented in Table 5, the heading duration recorded for each variety, Waha and Vitron were characterized by a short duration of 118 days. Wahbi, Semito, and GTA dur recorded a two-day longer period (+2 days) than the two previous varieties (120 days). Bousselem was characterized by duration of 122 days, while Cirta was distinguished by the longest heading duration, 124 days.

For the yields $(\mathrm{Y})$ results, they varied between $3.32 \pm$ 0.16 and $5.46 \pm 0.2 \mathrm{t} \mathrm{ha}^{-1}$, the maximum value of $5.46 \pm$ $0.22 \mathrm{t} \mathrm{ha}^{-1}$ was observed in GTA dur, while the minimum value of $3.32 \pm 0.16 \mathrm{t} \mathrm{ha}^{-1}$ was noted in Wahbi.

The values of the WTG ranged between $40.61 \pm 0.51$ and $47.33 \pm 0.20 \mathrm{~g}$. The highest value of $47.33 \pm 0.20 \mathrm{~g}$ was obtained in Cirta, whilst, the low value of $40.61 \pm 0.51$ $\mathrm{g}$ was recorded in the Waha variety.

The $\mathrm{Nb} \mathrm{S} / \mathrm{m}^{2}$ was very variable, The highest value of $265.00 \pm 1.73 \mathrm{~S} / \mathrm{m}^{2}$ was observed in GTA dur. However, the lowest value of $200.00 \pm 5.29 \mathrm{~S} / \mathrm{m}^{2}$ has been observed in Wahbi.

Table 4. Climatic data recorded during the campaign

\begin{tabular}{lccccccccccc}
\hline \multicolumn{1}{c}{ Month factors } & Sep & Oct & Nov & Dec & Jan & Fab & Mar & Apr & May & Jun & Total \\
\hline Precipitation $(\mathrm{mm})$ & 33 & 18.5 & 120.70 & 62.50 & 28.40 & 45.00 & 115.60 & 54.30 & 59.10 & 12.90 & 550 \\
Temperature average $\left({ }^{\circ} \mathrm{C}\right)$ & 24.35 & 18.79 & 12.40 & 09.21 & 07.49 & 07.40 & 09.71 & 11.15 & 13.53 & 17.72 & - \\
\hline
\end{tabular}


Table 5. Variables average values measured in the studied varieties $(n=3)$

\begin{tabular}{|c|c|c|c|c|c|c|c|}
\hline $\begin{array}{c}\text { Varieties } \\
\text { parameters }\end{array}$ & Waha & Cirta & Wahbi & Bousselem & Semito & GTA dur & Vitron \\
\hline RWC & $79.88 \pm 4.61$ & $62.34 \pm 8.63$ & $93.88 \pm 4.16$ & $69.90 \pm 2.16$ & $87.42 \pm 3.87$ & $71.02 \pm 0.22$ & $83.04 \pm 5.70$ \\
\hline $\mathrm{Chl} \mathrm{a}$ & $119.37 \pm 7.64$ & $115.43 \pm 3.48$ & $118.69 \pm 1.85$ & $137.58 \pm 2.94$ & $135.46 \pm 10.67$ & $169.94 \pm 14.99$ & $132.90 \pm 5.34$ \\
\hline Chl b & $90.78 \pm 2.19$ & $90.23 \pm 2.61$ & $90.70 \pm 6.32$ & $91.84 \pm 9.56$ & $91.79 \pm 1.04$ & $92.27 \pm 4.57$ & $90.92 \pm 4.29$ \\
\hline Chl t & $210.15 \pm 9.69$ & $205.66 \pm 5.92$ & $209.40 \pm 6.89$ & $229.42 \pm 10.50$ & $227.25 \pm 9.65$ & $262.22 \pm 19.45$ & $223.82 \pm 5.08$ \\
\hline Car & $40.06 \pm 3.11$ & $23.84 \pm 5.75$ & $40.03 \pm 1.84$ & $50.91 \pm 4.23$ & $44.23 \pm 1.93$ & $52.33 \pm 2.53$ & $42.12 \pm 5.50$ \\
\hline Pro & $0.49 \pm 0.13$ & $0.25 \pm 0.07$ & $0.97 \pm 0.06$ & $0.36 \pm 0.02$ & $0.75 \pm 0.04$ & $0.44 \pm 0.07$ & $0.53 \pm 0.05$ \\
\hline Ss & $0.65 \pm 0.06$ & $0.54 \pm 0.03$ & $0.87 \pm 0.04$ & $0.87 \pm 0.01$ & $0.73 \pm 0.01$ & $0.42 \pm 0.09$ & $0.49 \pm 0.03$ \\
\hline MDA & $1.82 \pm 0.01$ & $2.46 \pm 0.23$ & $1.74 \pm 0.07$ & $1.85 \pm 0.01$ & $1.78 \pm 0.02$ & $1.54 \pm 0.08$ & $1.81 \pm 0.06$ \\
\hline AFL & $35.36 \pm 0.59$ & $31.56 \pm 0.90$ & $31.30 \pm 0.76$ & $36.77 \pm 0.37$ & $31.40 \pm 0.49$ & $38.55 \pm 0.21$ & $29.14 \pm 2.85$ \\
\hline $\mathrm{PH}$ & $90.80 \pm 0.44$ & $81.40 \pm 1.15$ & $92.50 \pm 0.44$ & $86.00 \pm 1.32$ & $92.30 \pm 2.35$ & $81.44 \pm 0.59$ & $91.77 \pm 1.70$ \\
\hline $\mathrm{Nb} \mathrm{HT}$ & $4.00 \pm 1.00$ & $4.00 \pm 1.00$ & $4.00 \pm 1.00$ & $5.00 \pm 0.00$ & $4.00 \pm 0.00$ & $4.00 \pm 1.00$ & $4.00 \pm 1.00$ \\
\hline $\mathrm{Nb} \mathrm{ST}$ & $2.90 \pm 0.17$ & $2.40 \pm 0.10$ & $2.20 \pm 0.72$ & $3.00 \pm 0.00$ & $2.90 \pm 0.10$ & $3.20 \pm 0.26$ & $3.10 \pm 0.17$ \\
\hline LS & $6.80 \pm 0.26$ & $6.30 \pm 0.35$ & $6.20 \pm 0.26$ & $5.50 \pm 0.44$ & $5.80 \pm 0.72$ & $7.00 \pm 0.30$ & $6.50 \pm 0.70$ \\
\hline LSP & $17.00 \pm 0.30$ & $24.00 \pm 2.00$ & $17.50 \pm 0.50$ & $35.60 \pm 0.36$ & $20.00 \pm 1.80$ & $30.33 \pm 0.21$ & $23.10 \pm 1.05$ \\
\hline LB & $13.80 \pm 0.20$ & $15.37 \pm 0.25$ & $14.16 \pm 0.31$ & $16.200 \pm 0.26$ & $14.20 \pm 0.44$ & $17.50 \pm 0.20$ & $14.20 \pm 0.36$ \\
\hline $\mathrm{Nb}$ G/S & $41.40 \pm 1.97$ & $36.00 \pm 1.00$ & $39.40 \pm 1.22$ & $42.30 \pm 2.07$ & $40.10 \pm 2.15$ & $44.40 \pm 1.44$ & $43.40 \pm 1.44$ \\
\hline $\mathrm{Nb} \mathrm{S} / \mathrm{m}^{2}$ & $239.33 \pm 3.06$ & $220.00 \pm 2.65$ & $200.00 \pm 5.29$ & $237.00 \pm 6.24$ & $230.00 \pm 2.00$ & $265.00 \pm 1.73$ & $240.00 \pm 2.00$ \\
\hline WTG & $40.61 \pm 0.51$ & $47.33 \pm 0.20$ & $42.18 \pm 0.38$ & $45.27 \pm 0.06$ & $43.97 \pm 0.09$ & $46.45 \pm 0.22$ & $45.17 \pm 0.11$ \\
\hline HD & 118.00 & 124.00 & 120.00 & 122.00 & 120.00 & 120.00 & 118.00 \\
\hline GY & $4.02 \pm 0.14$ & $3.74 \pm 0.08$ & $3.32 \pm 0.16$ & $4.53 \pm 0.20$ & $4.05 \pm 0.23$ & $5.46 \pm 0.22$ & $4.70 \pm 0.14$ \\
\hline
\end{tabular}

For the $\mathrm{Nb} \mathrm{G} / \mathrm{S}$, the greatest value $44.40 \pm 1.44 \mathrm{G} / \mathrm{S}$ has been registered by GTA dur. While the lower value of $36.00 \pm 1.00 \mathrm{G} / \mathrm{S}$ was showed in Cirta variety. The Nb ST, it was found that the highest value of $3.200 \pm 0.26$ tillers plant $^{-1}$ was observed in the variety GTA dur and the lowest value $2.20 \pm 0.72$ tillers plant $^{-1}$ was detected in the variety Wahbi. Furthermore, a similarity for the Nb HT equal to $4.000 \pm 1.00$ tillers plants $^{-1}$ was registered in all the varieties with the exception of the Bousselem variety which discriminated by a Nb HT of $5.00 \pm 0.00$.

Regarding the morphological traits assessed. The HP varied depending on the variety. It fluctuates between $81.40 \pm 1.15$ and $92.50 \pm 0.44 \mathrm{~cm}$. The highest height $92.50 \pm 0.44 \mathrm{~cm}$ was noted in the Wahbi variety. The lowest height equal to $81.40 \pm 1.15 \mathrm{~cm}$ was recorded in the Cirta variety.

The AFL has varied between $29.14 \pm 2.85$ and $38.55 \pm$ $0.21 \mathrm{~cm}^{2}$. The largest area $38.55 \pm 0.21 \mathrm{~cm}^{2}$ was showed in the variety GTA dur. The smallest area of $29.140 \pm 2.85$ $\mathrm{cm}^{2}$ was recorded in Vitron variety.

The obtained results of the LSP showed that the longest peduncle $35.60 \pm 0.36 \mathrm{~cm}$ was recorded in the variety Bousselem while the shortest was observed in the variety Waha with $17.00 \pm 0.30 \mathrm{~cm}$.

For the LB, the values recorded for this parameter ranged between $13.80 \pm 0.20$ and $17.50 \pm 0.20 \mathrm{~cm}$, the longest beard $17.50 \pm 0.20 \mathrm{~cm}$ distinguished the GTA dur variety while the shortest beard was recorded by Waha $13.80 \pm 0.20 \mathrm{~cm}$.

The LS values varied from $5.50 \pm 0.44$ and $7.00 \pm 0.30$ $\mathrm{cm}$, the longest spike $7.00 \pm 0.30 \mathrm{~cm}$ was obtained in GTA dur variety, however, the shortest estimated at $5.50 \pm 0.44$ $\mathrm{cm}$ was detected in Bousselem.

At the physiological level, the RWC oscillated between $62.34 \pm 8.63$ and $93.88 \pm 4.16 \%$. The maximum value was recorded in Wahbi, in contrast, the minimum value was noted in Cirta. For the chlorophyll pigments; Chl (a), Chl (b), Chl (t) and Car; GTA dur recorded the best performing values $(169.94 \pm 14.99 ; 92.27 \pm 4.57 ; 262.22 \pm 19.45$ and $\left.52.33 \pm 2.53 \mu \mathrm{g} \mathrm{ml}^{-1} / \mathrm{FM}\right)$ unlike, Cirta revealed the lowest values $(115.43 \pm 3.48 ; 90.23 \pm 2.61 ; 205.66 \pm 5.92$ and $\left.23.84 \pm 5.75 \mu \mathrm{g} \mathrm{ml}^{-1} / \mathrm{FM}\right)$.

From a biochemical point of view, the results relating to the proline content of the leaves showed that Wahbi variety has the highest concentration estimated at $0.97 \pm 0.06 \mathrm{mg}$ $\mathrm{g}^{-1} \mathrm{FM}$, while the lowest concentration $0.25 \pm 0.07 \mathrm{mg} \mathrm{g}^{-1}$ FM was recorded in Cirta leaves.

The determination of the Ss revealed that Wahbi has accumulated greatest amount $0.87 \pm 0.04 \mathrm{mg} \mathrm{g}^{-1} \mathrm{FM}$ unlike GTA dur accumulated the smallest amount estimated at $0.42 \pm 0.09 \mathrm{mg} \mathrm{g}^{-1} \mathrm{FM}$. As for the MDA assay, the highest rate is noted in Cirta with a value of $2.46 \pm 0.23 \mathrm{nmol} \mathrm{g}^{-1}$ FM, while GTA dur recorded the lowest rate of $1.54 \pm 0.08$ nmol g ${ }^{-1}$ FM.

All the measured parameters ( $n=20$ variables) of the seven varieties were subjected to a principal component analysis (PCA). The correlations of the variables measured with the first two axes (axis 01 and axis 02) are shown in Figure 2; they explained 46.21 and $26.29 \%$ respectively, i.e., $72.5 \%$ of information. The plane formed by these two axes constitutes a basis for the interpretation of any correlation between these variables and the behavioral relationships of the different varieties as a function of these parameters.

Axis 1 (horizontal axis) is formed on the positive side by the majority of production characters such as $\mathrm{Nb} \mathrm{S} / \mathrm{m}^{2}$, $\mathrm{Nb} \mathrm{ST}$, Yield, and chlorophyll pigments, in addition to certain morphological characters such as AFL, LB and LSP. This axis could be defined as an axis of morphology and productivity. 
Axis 02 (vertical axis) is denoted by the strong contribution of $\mathrm{DH}$ and MDA on the negative side; while on the positive side of this axis the HP, RWC, and Pro are found at the same time. This axis can be qualified as a component of precocity, at heading stage, and of tolerance.

The graphical representation of the seven varieties (Figure 3) makes it possible to distinguish that: GTA dur was characterized by high values of the following variables: GY, $\mathrm{Nb} \mathrm{S} / \mathrm{m}^{2}$, $\mathrm{Nb} \mathrm{ST}, \mathrm{Nb} \mathrm{G} / \mathrm{S}, \mathrm{Chl}(\mathrm{a}), \mathrm{Chl}(\mathrm{t})$, Car, AFL, LS, and LB. However, this variety is distinguished by a short straw and a slight build-up of Pro, Ss, and MDA. In contrast, on the negative side, is Wahbi, which performed less well on the previous variables, this variety stands out for a higher HP, a high RWC and a strong accumulation of Pro and Ss. The variety Cirta was characterized by the lowest average values of all of the following variables: the content of chlorophyll pigments, HP, RWC and Pro and a late heading, while it has accumulated the greatest amount of MDA and it has the highest WTG. Bousselem was characterized by a dense herbaceous tillering, a short spike with a long peduncle, and also a relatively late heading. Moreover, Waha was distinguished by an early heading, a short peduncle and a barbecued and the lowest WTG. Vitron was distinguished by its narrowest AFL, short duration of heading. For Semito, this variety includes average values of all the studied variables.

PCA made it possible to organize phenotypic diversity among our seven varieties into four distinct groups according to the productivity, which proves that the studied varieties did not behave in the same way according to the climatic conditions of the agricultural year 2017/2018, which were more or less favorable to good agriculture.

Group 1 = GTA dur.

Group 2 = Vitron and Bousselem.

Group 3 = Cirta, Waha and Semito.

Group 4 = Wahbi.

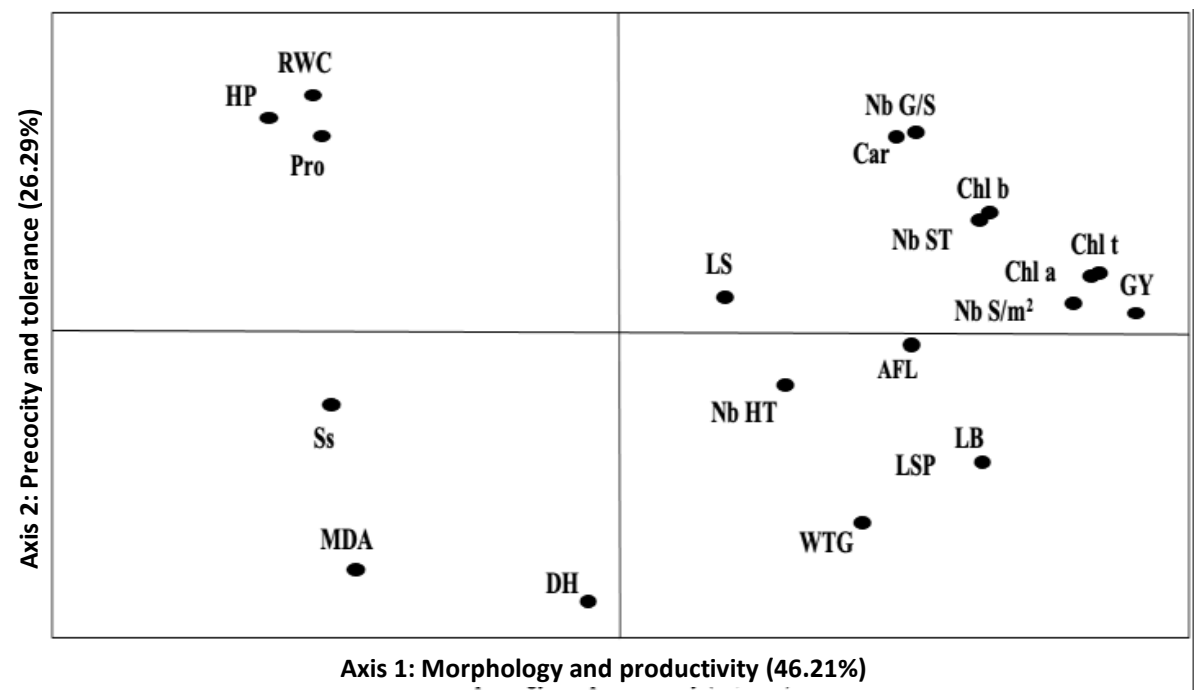

Figure 2. Correlations graph of 20 analyzed parameters

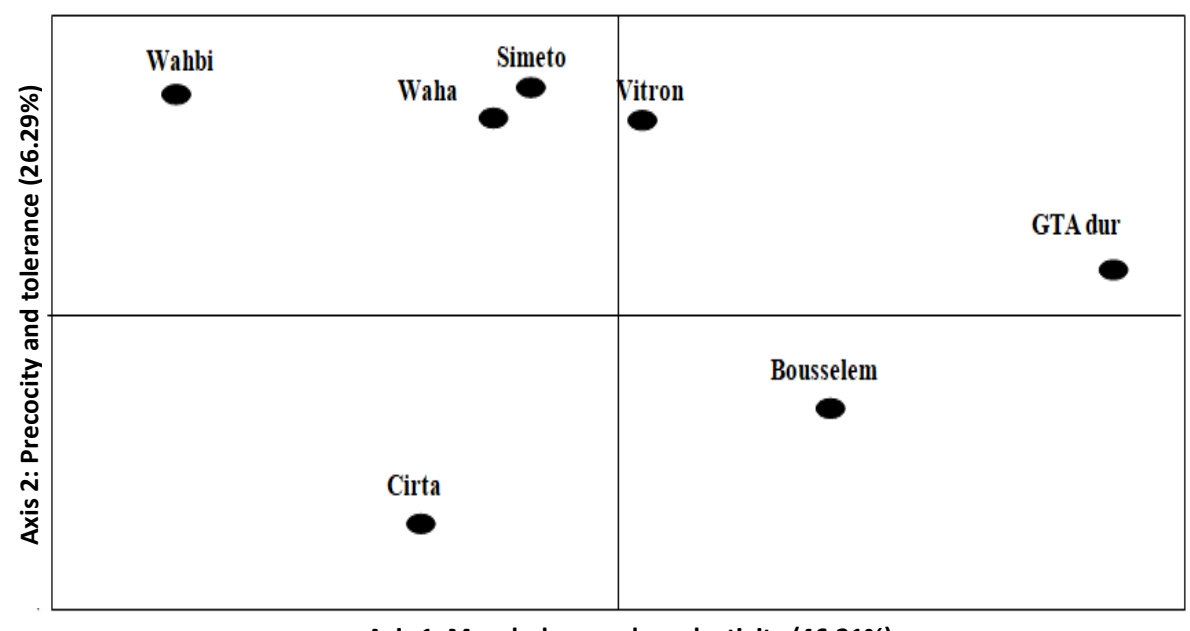

Axis 1: Morphology and productivity (46.21\%)

Figure 3. Distribution of varieties in function of two principal components 
To corroborate these results, a one-factor ANOVA analysis was carried out (Table 6). This test is limited to the parameter which discriminates the best-studied varieties, namely the GY (see Table 8). The test of homogeneity of the variances gave a Levene statistic of 0.449 ( $\mathrm{Sig}$. = 0.834 ) which expresses equality of the seven varieties variances.

The observed F value of 46.764 (Sig. $=0.000)$ indicates that the seven varieties do not have the same behavior in terms of production. The post hoc test of Newman-keuls revealed the existence of four groups (Table 6): the $1^{\text {st }}$ group consisted of the variety GTA dur, the $2^{\text {nd }}$ group was formed by the grouping of the three varieties Cirta, Waha and Semito, the $3^{\text {rd }}$ group included the two varieties Bousselem and Vitron, as well as the $4^{\text {th }}$ group consisted of the variety Wahbi.

Figure 4 shows that the distribution of varieties differs significantly in terms of productivity. Indeed, GTA dur was characterized by the highest average yield with $5.46 \pm 0.22$ $\mathrm{t} \mathrm{ha}{ }^{-1}$, followed by the $2^{\text {nd }}$ group that made up of two varieties Vitron and Bousselem which stood out with average yields of $4.70 \pm 0.14$, and of $4.53 \pm 0.20 \mathrm{t} \mathrm{ha}^{-1}$, respectively. Semito, Waha and Cirta form the $3^{\text {rd }}$ group that was characterized by almost similar averages of $4.02 \pm$ 0.23 , of $4.05 \pm 0.14$ and of $3.74 \pm 0.08 \mathrm{t} \mathrm{ha}^{-1}$, consecutively. Besides, Wahbi variety comes in the bottom of the classification with the lowest grain yield of $3.32 \pm$ $0.16 \mathrm{t} \mathrm{ha}^{-1}$.

\section{Cluster analysis}

The analysis of the hierarchical classification results made it possible to clarify the differences that exist between the different varieties based on the measured parameters (Figure 5).

The first group is represented by GTA dur and Bousselem varieties. They are the most profitable varieties given the higher or lower values of the yield and its components. These varieties seem to be well adapted to the environmental conditions, recording the highest values in terms of chlorophyll pigment content in the leaves, a large AFL and a long spike peduncle.

The second group includes the varieties Waha, Cirta, Semito and Vitron that showed average values of the different studied parameters. The third group is formed by the only Wahbi variety that presents a certain dissimilarity compared to the other varieties. It is distinguished by the least efficient production characters, as it is tolerant giving the high values of HP, RWC and of the rate of osmoregulators that it has displayed.

Table 6. Homogeneous groups according to the StudentNewman-Keuls test

\begin{tabular}{lcccc}
\hline \multirow{1}{*}{ Varieties } & \multicolumn{4}{c}{ Sub-division for $\boldsymbol{\alpha}=\mathbf{0 . 0 5}$} \\
\cline { 2 - 5 } & $\mathbf{1}$ & $\mathbf{2}$ & $\mathbf{3}$ & $\mathbf{4}$ \\
\hline Wahbi & $33.245_{\mathrm{a}}$ & & & \\
Cirta & & $37.481_{\mathrm{b}}$ & & \\
Waha & & $40.22 \mathrm{~b}_{\mathrm{b}}$ & & \\
Semito & & $40.563 \mathrm{~b}$ & & \\
Bousselem & & & $45.370_{\mathrm{C}}$ & \\
Vitron & & & $47.052_{\mathrm{C}}$ & \\
GTA dur & & & & $54.673_{\mathrm{d}}$ \\
Signification & 1 & 0.122 & 0.267 & 1 \\
\hline
\end{tabular}

Note: $a, b, c$ and $d$ indicate the homogeneous groups

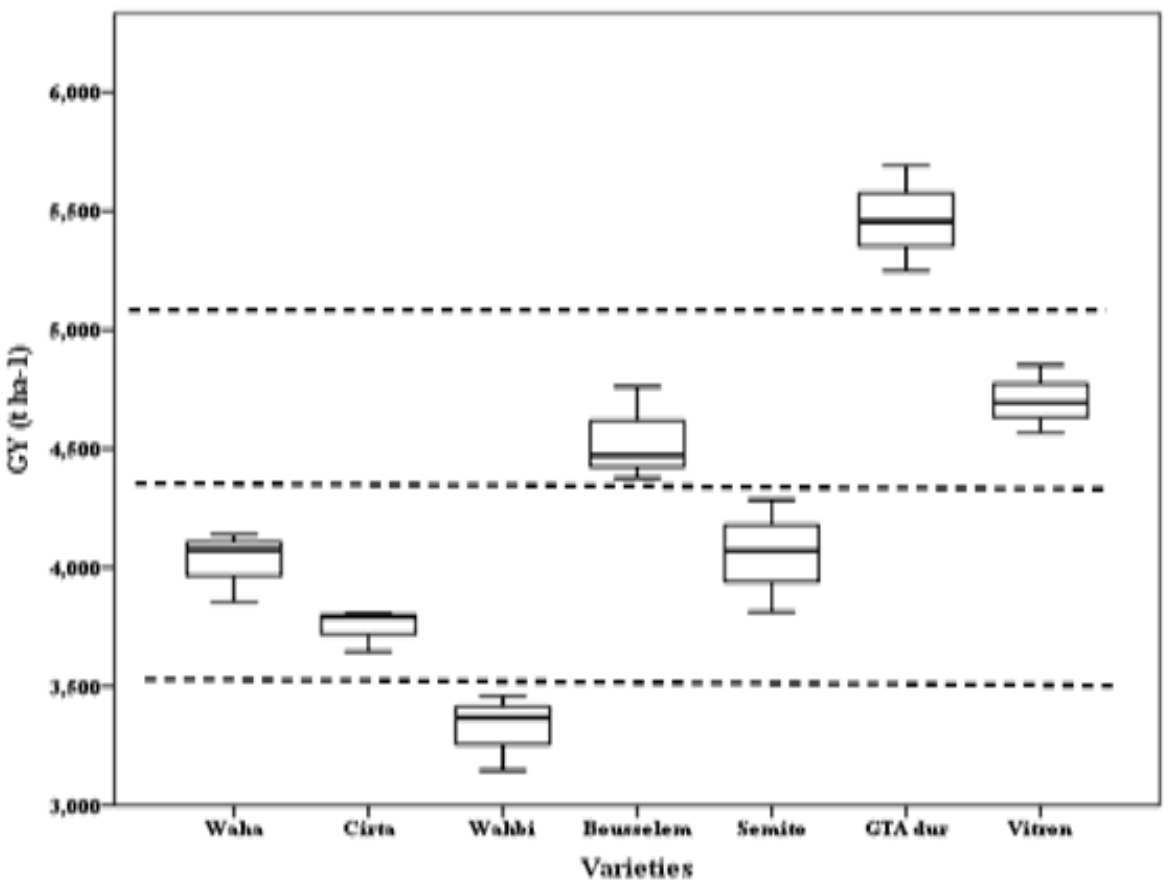

Figure 4. Graphical comparison of grain yied (GY) averages 


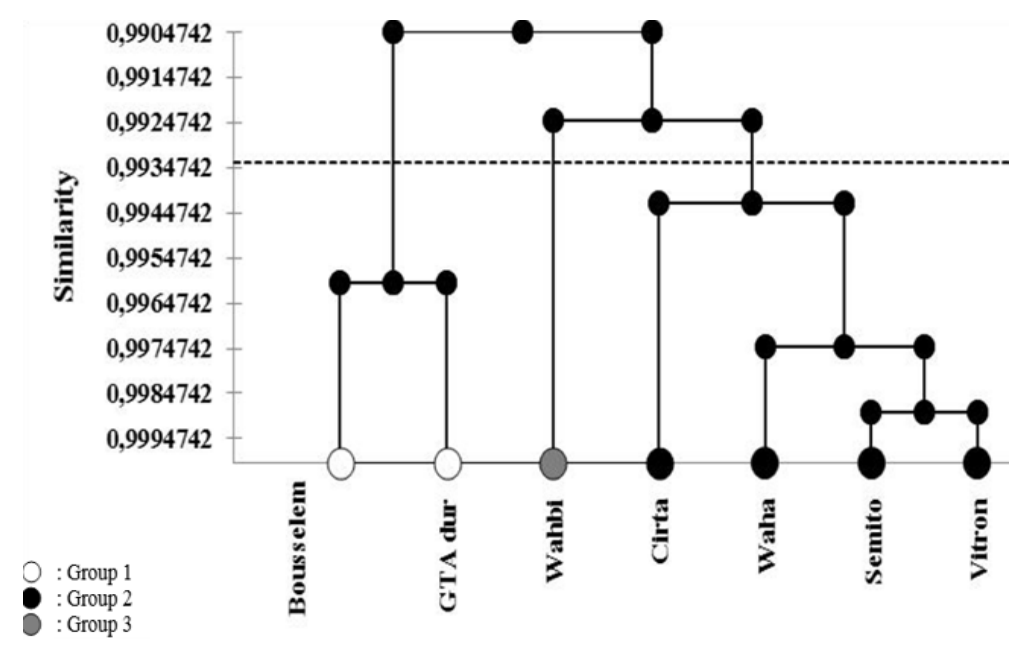

Figure 5. Ascending hierarchical classification (AHC) of studied durum wheat varieties based on the measured parameters.

\section{Discussion}

In the present work, seven varieties of durum wheat were evaluated on the basis of numerous agromorphological, physiological and biochemical traits in order to extract the most useful traits that can be used by breeders in a breeding program. The results showed an important diversity between the studied varieties which would be attributed to the genetic heritage of each variety as well as to the environment in which they were regenerated.

The phenological monitoring results revealed that the duration between the sowing and the heading of the different studied varieties varied from 118 to 124 days. Couvreur (1985) reported that the earliness of a variety is determined from the duration length of the development cycle from the sowing to the heading stage. According to this author, a variety is considered early if the duration is less than 100 days; it is semi-early if the duration is between 100 and 120 days, and tardy if this duration exceeds 120 days. On this basis, our varieties can be classified into two groups: the ${ }^{\mathrm{s} e}$ semi-early group including Waha, Vitron, Wahbi, Semito, as well GTA and the $2^{\text {nd }}$ is tardy group comprising the two varieties Bousselem, and Cirta. On the other hand, it appears that the GY has represented the most discriminating characteristic between the studied varieties.

According to Kara and Bellkhiri (2011) annual variations in climatic conditions make the selection based solely on the yield is difficult. The results of several studies exhibited that the grain yield is very variable, polygenic and the most often subject to strong genotype by environment $(\mathrm{G} \times \mathrm{E})$ interactions (Benmahammed et al. 2010; Sanchez-Garcia et al. 2012; Semcheddine et al. 2017). For this reason, breeders often use the indirect selection and the traits that are well correlated with the yield to improve grain yields in dry environments (Sallam et al. 2014). However, the principal components analysis (PCA) makes it possible to highlight the different correlations between the measured variables, ranging from a weak to a strong correlation. The study of these relations and their good understanding are interesting for the breeder who seeks to identify the effect of the characters, easily measurable very early in the development cycle of the plant (DH, HP, AFL, LSP, LB, LS, RWC, Pro, Ss, MDA, etc.), on more complex characteristics such as Nb G/S, WTG, and Yield, that are measured at the harvesting stage by destructive and relatively less precise methods (Kirouani et al. 2019). The correlation matrix (Table 7) displays that the DH is negatively correlated with the $\mathrm{Nb} \mathrm{S} / \mathrm{m}^{2}(\mathrm{r}=-0.276)$, the $\mathrm{Nb} G / \mathrm{S}(\mathrm{r}=-0.637)$, and the Yield $(\mathrm{r}=-0.213)$. This means that more or less early growth gives a high $\mathrm{Nb} \mathrm{S} / \mathrm{m}^{2}$ as well as a big $\mathrm{Nb} \mathrm{G} / \mathrm{S}$; which leads to a gain in grain yield of durum wheat. These results are in agreement with those observed by Mansouri et al. (2018). Similarly, Chennafi et al. (2010) found in their work that cultivars with early headings are more productive than those characterized by tardy heading. Chentoufi et al. (2014) considered that the earliness at the heading stage and that at maturity as important selection criteria, are parameters of tolerance and adaptation to climatic constraints.

Considering the random distribution of precipitation in arid to semi-arid regions, the adoption of relatively shortcycle varieties is necessary, this biological mechanism is a desirable feature and could be quantified as evasion since early genotypes can accomplish their cycle through avoiding also terminal drought (Megherbi et al. 2012). Nevertheless, the increase in the earliness of cereals, although it has given undeniable results, is not without drawbacks, it contributes, among other things, to the reduction of productivity and is only suitable for late drought and short duration (Melki and Dahmane 2008). Slafer et al. (2005) demonstrated that, in the absence of stress, the late genotypes are generally more productive than early ones. This is due to the fact that the early genotypes make less use of the availabilities offered by the production medium. 
Table 7. Correlation coefficients matrix of the various analyzed variables

\begin{tabular}{|c|c|c|c|c|c|c|c|c|c|c|c|c|c|c|c|c|c|c|c|c|}
\hline & RWC & Chl a & Chl b & Chl T & Car & Pro & Ss & MDA & AFL & PH & $\begin{array}{l}\text { Nb } \\
\text { HT }\end{array}$ & $\begin{array}{l}\text { Nb } \\
\text { ST }\end{array}$ & $\mathbf{L S}$ & LSP & $\mathbf{L B}$ & $\mathbf{N b} \mathbf{G} / \mathbf{S}$ & $\begin{array}{c}\mathrm{Nb} \\
\mathrm{S} / \mathrm{m}^{2} \\
\end{array}$ & WTG & D H & GY \\
\hline RWC & 1.000 & & & & & & & & & & & & & & & & & & & \\
\hline $\mathrm{Chl}$ a & -0.202 & 1.000 & & & & & & & & & & & & & & & & & & \\
\hline Chl b & -0.042 & 0.884 & 1.000 & & & & & & & & & & & & & & & & & \\
\hline Chl T & -0.197 & 1.000 & 0.893 & 1.000 & & & & & & & & & & & & & & & & \\
\hline Car & 0.205 & 0.762 & 0.891 & 0.771 & 1.000 & & & & & & & & & & & & & & & \\
\hline Pro & 0.952 & -0.164 & -0.008 & -0.159 & 0.174 & 1.000 & & & & & & & & & & & & & & \\
\hline Ss & 0.420 & -0.427 & -0.029 & -0.413 & 0.123 & 0.496 & 1.000 & & & & & & & & & & & & & \\
\hline MDA & -0.536 & -0.634 & -0.693 & -0.639 & -0.881 & -0.498 & -0.062 & 1.000 & & & & & & & & & & & & \\
\hline AFL & -0.457 & 0.612 & 0.627 & 0.615 & 0.576 & -0.384 & -0.053 & -0.379 & 1.000 & & & & & & & & & & & \\
\hline HP & 0.908 & -0.405 & -0.172 & -0.398 & 0.106 & 0.764 & 0.467 & -0.354 & -0.548 & 1.000 & & & & & & & & & & \\
\hline $\mathrm{Nb} \mathrm{HT}$ & -0.333 & 0.114 & 0.366 & 0.124 & 0.422 & -0.321 & 0.529 & -0.011 & 0.425 & -0.178 & 1.000 & & & & & & & & & \\
\hline $\mathrm{Nb} \mathrm{ST}$ & -0.205 & 0.725 & 0.706 & 0.728 & 0.69 & -0.375 & -0.446 & -0.507 & 0.447 & -0.111 & 0.220 & 1.000 & & & & & & & & \\
\hline LS & -0.079 & 0.263 & -0.113 & 0.249 & -0.059 & -0.133 & -0.755 & -0.214 & 0.205 & -0.215 & -0.667 & 0.203 & 1.000 & & & & & & & \\
\hline LSP & -0.653 & 0.606 & 0.594 & 0.608 & 0.481 & -0.597 & -0.074 & -0.058 & 0.586 & -0.648 & 0.75 & 0.483 & -0.27 & 1.000 & & & & & & \\
\hline $\mathrm{LB}$ & -0.666 & 0.769 & 0.612 & 0.766 & 0.413 & -0.52 & -0.324 & -0.14 & 0.727 & -0.846 & 0.367 & 0.375 & 0.118 & 0.844 & 1.000 & & & & & \\
\hline $\mathrm{Nb} \mathrm{G} / \mathrm{S}$ & 0.124 & 0.743 & 0.694 & 0.745 & 0.872 & -0.009 & -0.255 & -0.823 & 0.459 & 0.085 & 0.204 & 0.836 & 0.294 & 0.394 & 0.339 & 1.000 & & & & \\
\hline $\mathrm{Nb} \mathrm{S} / \mathrm{m}^{2}$ & -0.422 & 0.807 & 0.666 & 0.805 & 0.577 & -0.525 & -0.640 & -0.420 & 0.628 & -0.414 & 0.087 & 0.921 & 0.45 & 0.516 & 0.589 & 0.752 & 1.000 & & & \\
\hline WTG & -0.702 & 0.418 & 0.202 & 0.412 & -0.100 & -0.608 & -0.491 & 0.376 & 0.060 & -0.758 & 0.157 & 0.183 & -0.074 & 0.668 & 0.690 & -0.056 & 0.308 & 1.000 & & \\
\hline $\mathrm{DH}$ & -0.659 & -0.139 & -0.13 & -0.139 & -0.424 & -0.452 & 0.138 & 0.702 & 0.088 & -0.677 & 0.354 & -0.426 & -0.442 & 0.444 & 0.443 & -0.637 & -0.276 & 0.640 & 1.000 & \\
\hline GY & -0.379 & 0.901 & 0.727 & 0.898 & 0.660 & -0.449 & -0.604 & -0.478 & 0.555 & -0.432 & 0.17 & 0.889 & 0.354 & 0.657 & 0.698 & 0.815 & 0.943 & 0.464 & -0.213 & 1.000 \\
\hline
\end{tabular}

Table 8. Components' matrix

\begin{tabular}{|c|c|c|c|c|c|c|c|c|c|c|c|c|c|c|c|c|c|c|c|c|}
\hline & GY & Chl a & Chl T & $\begin{array}{c}\mathrm{Nb} \\
\mathrm{S} / \mathrm{m}^{2}\end{array}$ & LB & Chl b & Nb ST & LSP & Nb G/S & AFL & Car & Ss & Nb HT & $\mathbf{L S}$ & D H & RWC & MDA & HP & Pro & WTG \\
\hline Axe 1 & 0,960 & 0.932 & 0.932 & 0.906 & 0.83 & 0.821 & 0.818 & 0.769 & 0.751 & 0.732 & 0.715 & -0.448 & 0.322 & 0.235 & -0.046 & -0.457 & -0.475 & -0.543 & -0.462 & 0.472 \\
\hline Axe 2 & 0.084 & 0.186 & 0.192 & 0.091 & -0.409 & 0.311 & 0.283 & -0.413 & 0.581 & -0.059 & 0.58 & 0.188 & -0.225 & 0.161 & -0.898 & 0.85 & -0.844 & 0.777 & 0.732 & -0.698 \\
\hline
\end{tabular}


However, wheat is generally cultivated in rainy conditions in the Mediterranean region which often imposes a certain number of environmental constraints on tardy varieties. The varietal selection based on the earliness must favor obtaining varieties with an earliness date of Heading, which varies from one year to another, should coincide with the optimum heading period. Obtaining optimum and stable productivity depends on obtaining this type of variety. To achieve this goal, this selection should relate to both the thermo-periodic and the photo-periodic requirements of the plant (Mekhlouf et al. 2006).

DH also has shown a positive correlation with WTG ( $\mathrm{r}$ $=0.640)$. According to Samira et al. (2011), developmental delay allows the plant to accumulate energy and resources to combat stress, before the imbalance between the inside and the outside of the body increased to threshold where the damage will be irreversible. The link is explained by a greater accumulation of reserves; consequently, the grains are well filled. Similar results have been obtained in the work of Al-Doss et al. (2010) $(r=0,370)$.

The GY presents positive correlations with the components : $\mathrm{Nb} \mathrm{S} / \mathrm{m}^{2}(\mathrm{r}=0.943), \mathrm{Nb} \mathrm{G} / \mathrm{S}(\mathrm{r}=0.815)$, and WTG $(r=0.464)$. The varieties Bousselem, Vitron, and GTA dur gave the highest values for these traits and, therefore, they displayed the highest yields. These results are in agreement with several studies that showed that the yield is the result of several characters that contribute to its achievement (Kahrizi et al. 2010; Lopes et al. 2012; Farshadfar et al. 2013). In the light of these results, the best yields were observed due to the high $\mathrm{Nb} \mathrm{S} / \mathrm{m}^{2}$ and to the high $\mathrm{Nb} \mathrm{G} / \mathrm{S}$ which are in agreement with those obtained by several researchers (Mazouz and Bouzerzour 2017; Kizilgeci 2019). Fellahi et al. (2019) stated that the number of grains per spike and the number of ears per plant have high direct effects on yield. This does not exclude the important role of WTG in the expression of yield. Erchidi et al. (2000) reported that the indirect contribution of this component to yield, under variable climates, is greater via the number of grains per spike than their direct contribution. Furthermore, Whan et al. (2014) showed that seed size is a very important part of basic plant research, since, in plant reproduction, seed formation and development had significant effects, as well as cereal breeding, as a related trait yield and vigor. Grain size and shape are two among main targets in wheat breeding programs, due to their significant effect on grain weight and yield (Okamoto et al. 2013; Rasheed et al. 2014). Similar results of relationships between grain yield and WTG have been observed in previous studies (Ferdous et al. 2010; Khan et al. 2013; Zoghmar et al. 2016; Safarova et al. 2019).

In addition, the Yield is positively correlated with the $\mathrm{Nb}$ ST $(\mathrm{r}=0.889)$. According to Khan and Naqvi (2011) tillering is a varietal character, which under favorable conditions, could provide information on the potential of varieties. He also noted that the number of tillers per plant has direct contribution towards grain yield. It means, as the number of productive tillers increases there will be simultaneous increase in yield. Our results agree with the observations made by Sang et al. (2014) who concluded that tiller formation affects grains number and grain weight, therefore it is closely related to yield, besides, Hazmoune and Benlaribi (2004) found that the ability of a plant to form a large number of tillers is very beneficial for increasing and stable yield in variable environments. Understanding this contribution can help in the selection of suitable and highly productive genotypes (Elhani et al. 2007).

From the results presented in Table 7 , it emerges that the AFL has significant and positive correlations with the yield, the spike characteristics (LS, LSP and LB), as well as with all the chlorophyll pigments. Overall, these results are in agreement with those of Salmi et al. (2015) who reported that a flag leaf with large dimensions is certainly desirable in favorable environmental conditions, since this organ is the last, which remains inactivity, with the spike and the beards. An increase in AFL induces an increase in the photosynthetic capacity for the synthesis of organic compounds that are favorable to a high yield. Since the productivity of a plant is linked to its growth capacities, in the event of stress causing the decrease in FLA as well as in the vegetative part of the plant and, therefore, in the photosynthesis, the priority of the plant is to preserve its ability to produce at least one viable seed. Thus, it, therefore, implements a process of abortion of seeds that cannot be filled for the lack of sufficient resources. Our results are also supported by other studies (Guendouz et al. 2012; Allam et al. 2015; Himani et al. 2018).

The HP showed negative and significant associations with the yield and their components (Table 7). These results mean that the varieties with short straws present the best values for the agronomic characteristics. Our results are in agreement with those of several studies showing that short plants are more productive than tall straw plants. Since the short ones have a significant tillering capacity, each tiller will lengthen and put an inflorescence which increases the spike stand, consequently, an increase in yield (Benniou et al. 2018). In the same context, Kirouani et al. (2019) obtained similar results to ours and they attributed the reason to the fact that tall varieties do not have the capacity to provide the energy and the assimilates necessary for the formation of spikes and the elongation of tillers at the same time. However the great length of the plant has many advantages such as adaptation to the lack of water at the end of the cycle, thus ensuring a good filling of the grain and the use of straw in animal feed breeding when the stem pith is absent or thin (Zerafa et al. 2017).

It is also important to note the positive correlation recorded between the characteristics of the spike (LS, LSP, and LB), and the yield and its components. This is corroborated with the hypothesis presented by Guo et al. (2018), who assumed that it was possible to maximize grain yield by manipulating and predicting wheat spike morphology. Kahali et al. (2016) explained the role of the peduncle by the quantity of photosynthetic assimilates stored in this part of the plant, which are likely to be transferred to the grains, while Kong et al. (2010) also felt that the peduncle contributes crucially during the final 
stages of grain filling. Regarding to the LS, many authors have pointed out the important role of a long spike (Subhashchandra et al. 2009; Rebetzke et al. 2016) reported that the length of the spike has a positive and a high direct effect on the yield/plant. Likewise, Merah and Monneveux (2014) reported that beards play an important role in the stress tolerance and in the filling of grains by their developed surface, their upright port and their position in the immediate vicinity of the seed that promotes its formation, which would make a gain performance.

The mechanisms of adaptation and of tolerance to abiotic constraints are diverse. For example, the measurement of the relative water content (RWC) makes it possible to describe in a global way the water status of the plant, reflecting the metabolic activity of the tissues and used as the most significant index of tolerance to stress in particular dehydration Sallam et al. (2019). It has also been proposed as a useful trait for breeding stress-tolerant wheat varieties (Hasheminasab et al. 2012; Farshadfar et al. 2014). The obtained results showed that the RWC reveals a negative correlation with the yield. The varieties Wahbi, Waha, and Semito showing the highest RWCs, are relatively the least productive, with the exception of the variety Cirta, which seems to have little tolerance for the yield compared to other varieties. This is perfectly similar to the results obtained by Khennaoui et al. (2016) who recorded a negative relationship $(\mathrm{R}=-0.466)$ between RWC and Yield, and on the basis of previous studies, they have been concluded that genotypes tolerant to abiotic stress are less productive and lose less water leaf area per unit of time. In addition, the RWC shows negative correlations with the following parameters: AFL, LSP and LB this means that the narrow AFL and the characteristics of a short spike contribute to a limitation of water losses. Similar results have been reported by other studies (Salmi 2015; Khennaoui et al. 2016). On the other hand, it appears that varieties with a high height have a high RWC; these results correspond to those obtained by Jatoi et al. (2011). Elevated RWC is a form of resistance which probably results from active osmoregulation, by a mechanism of stress tolerance, by osmotic adjustment which results in an increase in osmotic potential due to an accumulation of osmolytes in the cytoplasm such as proline and soluble sugars. Chaib et al. (2015) clarified the important role of these osmolytes in osmo-regulation in order to ensure the optimal physiological functioning of the cell, especially under stressful conditions. Positive correlations were observed in our study between RWC and Pro $(\mathrm{r}=0.952)$ and Ss $(r=0.420)$. These results suggest that the varieties with the highest relative water content accumulate more Ss and Pro. These results are supported by the findings of Sassi et al. (2012). MDA is negatively correlated with RWC and chlorophyll pigments (Table 7). This suggests that the peroxidation of the membrane lipids would be associated with a malfunction and lead to the damage of the main cellular components, consequently, the membrane then loses its integrity by becoming permeable, plasmolysis and releases, towards the extracellular space, its contents, which seriously affects the productivity of the plant; in general. Similar results have been obtained in many species, such as (colza) (Brassica napus L.) (Toumi et al. 2014), soft wheat (Triticum aestivum) (Khalilzadeh et al. 2016), and durum wheat (Triticum durum) (Bouchemal et al. 2018). Besides, the presence of a negative correlation between Pro, Ss and MDA (Table 7) could be explained by the role of these compounds in the protection of cell membranes. Hacini and Brinis (2012) pointed out that osmo-protection is another trait for which researchers are unanimous in its participation in the tolerance of genotypes. The diversity of responses, even if basically, proteolysis necessarily leads to an accumulation of solutes such as proline and soluble sugars, proves that genotypes react differently depending on their genetic origin. On the other hand, the result of study by Salmi (2015) suggested that the accumulation of these osmolytes seems much more intended for stress tolerance but it is not able to have a contribution to the expression of yield in semi-arid areas. Maury et al. (2011) and Simonneau et al. (2014) mentioned that the fundamental biological mechanisms, of tolerance to droughts such as the reduction of the leaf surface, the closure of stomata, the osmotic regulation, which contribute to the maintenance of a water balance, between the plant and the soil, hinder the growth and the photosynthesis, are the main physiological functions of the plant, that leads to certain yield losses. Our results are consistent with those obtained by Fellah et al. (2002), who revealed a negative relationship between adaptation, as measured by tolerance to caloric stress, and grain yield. Sensitive varieties produce more under stress compared to tolerant varieties. Menad et al. (2011) recorded that highly productive genotypes suffer greater yield reduction under drought conditions compared to moderately yielding genotypes.

In conclusion, the obtained results revealed the existence of variability for most of the measured parameters in the studied varieties. This variability is only an ineluctable consequence of genetic variation which constitutes a gain that must rationally be preserved, enriched and valued according to the drowned objectives. Indeed, the phenology analysis (duration of heading) has revealed an inter-specific variability in the studied varieties, and has demonstrated that the use of more or less early varieties is favorable to the expression of grain yield; in which the varieties had the most important values for all the morpho-physiological parameters were those presented the highest yields. These findings lead us also to conclude that in order to improve the performance of cereals in areas dominated by conditions similar to those of our study area, it is recommended to develop a plant material characterized by good productivity $\left(\mathrm{Nb} \mathrm{S} / \mathrm{m}^{2}, \mathrm{Nb} \mathrm{G} / \mathrm{S}\right)$ and adaptive (AFL, LS, LSP, LB) qualities; able to maintain its photosynthetic activity as long as possible with a stable yield. Finally, it should be noted that these types of studies require conducting both multi-site and multi-year behavioral tests to determine and characterize the performing genotypes; with a good approximation for the target environment; as well as they must be completed by molecular biology techniques that can help to identify desirable genes to support future durum wheat improvement programs. 


\section{REFERENCES}

Aghaee M, Mohammad R, Nabovati S. 2010. Agro-morphological characterization of durum wheat accessions using pattern analysis. Aust J Crop Sci 4 (7) : 505.

Al-Doss AA, Saleh M, Moustafa KA, Elshafei AA, Barakat MN. 2010. Grain yield stability and molecular characterization of durum wheat genotypes under heat stress conditions. Afr J Agric Res 5 (22) : 3065 3074.

Allam A, Tirichine A, Madani H, Benlamoudi W, Attali Y. 2015. Agronomic and morphological evaluation of the cultivars of durum wheat: (Triticum Durum Desf.) cultivated in the Palm Groves of the Valley of Oued Righ, Algerian South-Est. Rev des Bioressources 5 (2): 10-10.

Amallah L, Hassikou R, Rhrib K, Gaboun F, Ennadir J, Bouazza F, Rochd A, Arahou M, Diria G, Taghouti M. 2016. Analyse de la diversité génétique d'une collection de blé dur par les marqueurs agromorphologiques et biochimiques. J Mater Environ Sci 7 (7) : 2435 2444.

Barrs HD. 1968. Determination of water deficits in plant tissues. Water Deficit and Plant Growth 235-368.

Benmahammed A, Nouar H, Haddad L, Laala Z, Abdelmalek O, Bouzerzour H.2010. Analyse de la stabilité des performances de rendement du blé dur (Triticum durum Desf.) sous conditions semiarides. Biotechnol Agron Soc Environ 14 (1) :177-186.

Benniou R, Badache F, Regoub A, Bendada H. 2018. Etude comparative du comportement et de l'adaptation de différents génotypes de blé dur (Triticum durum Desf.) en zone semi-aride dans l'Est de l'Algérie. Rev Agric 9 (1) : 16-31.

Bouchemal K, Bouldjadj R, Belbekri M, Ykhlef N, Djekoun A. 2018. Pigments photosynthétiques, enzymes antioxydantes et potentiel osmotique foliaire de dix génotypes de blé dur (Triticum durum Desf.) : Effet du stress hydrique. Phytoprotection 98 (1):13-24.

Chaib G, Benlaribi M, Hazmoune T. 2015. Accumulation d'osmoticums chez le blé dur (Triticum durum Desf.) sous stress hydrique. Eur Sci J 11 (24): 378-395.

Chehili F, Boudour L, Bouchtab K. 2017. Etude de la variabilité agronomique et biochimique des quatre génotypes d'une variété de blé dur cultivé en Algérie (Triticum durum Desf.). Eur Sci J 13 (9) : 409-425.

Chennafi H, Makhlouf M, Ayadi AL. 2010. Réponse des variétés contrastées de blé dur (Triticum durum Desf.) à la date d'implantation sous semis direct en milieu semi-aride. In : Bouzerzour H, Irekti H, Vadon B (éds); 4. Actes des Rencontres Méditerranéennes du Semis Direct. Sétif, 03-05 Mai 2010. [Algérie]

Chentoufi L, Sahri A, Arbaoui M, Birouk A, Roumet P, Muller M. H, Belqadi H. 2014. Diversité agro-morphologique et gestion variétale par les agriculteurs du blé dur (Triticum turgidum ssp. durum) dans le Pré-Rif marocain. Rev Marocaine Sci Agron Vet 2 (2) : 30-38.

Couvreur F. 1985. Formation du rendement du blé et risque climatiques. Perspectives agricoles 95: 12-15.

Dubois M, Gilles KA, Hamilton JK, Rebers PT, Smith F. 1956 Colorimetric method for determination of sugars and related substances. Anal Chem 28 (3) : 350-356.

Erchidi AE, Talouizte A, Benbella M. 2000. Relation entre certains paramètres contrôlant les pertes en eau et le rendement grain chez neuf variétés de blé dur soumises au stress hydrique. In : Royo C, Nachit M, Di Fonzo N, Araus J.L (éds); Seminar on Durum Wheat Improvement in the Mediterranean Region: New Challenges. Zaragoza, 12-14 Avril 2000. [Spain]

Farshadfar E, Romena H, Shabani A. 2013. Evaluation of genetic parameters in agro-physiological traits of wheat (Triticum aestivum L.) under irrigated condition. Intl J Adv Biol Biomed Res 4 : 319-326.

Farshadfar E, Ghasemi M, Rafii F. 2014. Evaluation of physiological parameters as a screening technique for drought tolerance in bread wheat. J Biodivers Environ Sci 4: 175-186.

Fellah A, Bouzerzour H, Benmahammed A, Djekoun A. 2002. Sélection pour améliorer la tolérance aux stress abiotiques chez le blé dur (Triticum durum Desf.). Rev Marocaine Sci Agron Vet 22 (3) : 161 168.

Fellahi Z, Hannachi A, Guendouz A, Rabti A, Bouzerzour H. 2019 Heritability, correlations and selection gain in F2 early generation of bread wheat (Triticum aestivum L.) under semi-arid conditions. J Algérien des Régions Arides 13 (2) : 37- 49.
Ferdous MF, Shamsuddin AKM, Hasna D, Bhuiyan MMR. 2010. Study on relationship and selection index for yield and yield contributing characters in spring wheat. J Bangladesh Agric Univ 8: 191-194.

Ghennai A, Zerafa C, Benlaribi M. 2017. Étude de la diversité génétique de quelques variétés de blé tendre (Triticum aestivum L.) et de blé dur (Triticum durum Desf.) selon la base des caractères de l'UPOV. J Appl Biosci 113 (1): 11246-11256.

Guendouz A, Maamari K, Guessoum S, Hafsi M, Benidir M. 2012. Flag leaf senescence, chlorophyll content and its relationships with yield components under drought in durum (Triticum durum Desf.). Intl J Innovations Bio-Sci 2 (4): 186-192.

Guo Z, Zhao Y, Röder MS, Reif JC, Ganal MW, Chen D, Schnurbusch T. 2018. Manipulation and prediction of spike morphology traits for the improvement of grain yield in wheat. Sci Rep 8 (1): 1-10.

Hacini N, Brinis L. 2012. Utilisation de quelques marqueurs physiologiques et biochimiques dans l'expression de tolérance au stress hydrique chez 10 génotypes de blé dur (Triticum durum Desf.). Synthèse: Rev Sci Technol 25 (1): 6-16.

Hasheminasab H, Assad MT, Aliakbari A, Sahhafi SR. 2012. Evaluation of some physiological traits associated with improved drought tolerance in Iranian wheat. Ann Biol Res 3 (4) :1719-1725.

Hazmoune T, Benlaribi M. 2004. Etude comparative de l'effet de la profondeur de semis sur les caractères de production de trois genotypes de (Triticum durum Desf.) en zone semi-aride. Sci Technol C, Biotechnols 94-99.

Himani SM, Renu M. 2018. Morpho-physiological characterization of durum wheat (Triticum durum Desf.) genotypes under irrigated conditions. Intl Curr Microbiol Appl Sci 7 (2): 2350-2354.

Jatoi WA, Baloch MJ, Kumbhar MB, Khan NU, Kerio MI. 2011. Effect of water stress on physiological and yield parameters at anthesis stage in élite spring, wheat cultivars. Sarhad J Agric 27 (1): 59-65.

Kahali L, Djekoun A. 2016. Analyse génotypique de la contribution de la matière assimilée du pédoncule dans le remplissage du grain chez le blé dur (Triticum durum Desf.). Eur Sci J 12 (18): 151-166.

Kahrizi D, Maniee M, Mohammadi R, Cheghamirza K. 2010. Estimation of genetic parameters related to morpho-agronomic traits of Durum Wheat (Triticum turgidum var. durum). Biharean Biol 4 (2): 93-97.

Kara Y, Bellkhiri C. 2011. Study of the adaptation to water stress of some durum wheat and related wild species: Potential interest of these species for the improvement of the yield. Courier du Savoir 11: 119126.

Khalilzadeh RRS, Sharifi, Jalilian J. 2016. Antioxidant status and physiological responses of wheat (Triticum aestivum L.) to cycocel application and biofertilizers under water limitation condition. J Plant Interact 11: 130-137.

Khan N, Naqvi FN. 2011. Effect of water stress in bread wheat hexaploids. Curr Res J Biol Sci 3 (5): 487-498.

Khan AA, Alam MA, Alam MK, Alam MJ, Sarker ZI. 2013. Correlation and path analysis of durum wheat (Triticum turgidum L. var. Durum). Bangladesh J Agric Res (3): 515-521.

Khennaoui A, Djekoun A, Benbelkacem A, Ykhlef N. 2016. Agro morphological characterization and study of grain yield of Algerian durum wheat (Triticum durum Desf.). Intl J Adv Res 4 (11) : 10711080.

Khennaoui A. 2018. Diversité phénotypique et moléculaire du blé dur cultivé en Algérie: Identification et caractérisation des accessions. [Thèse]. Université des Frères Mentouri, Constantine. [Algérie]

Kirouani A, Kiar RO, Boukhalfoun L, Fellahi ZEA. 2019. Caractérisation de quelques variétés Algériennes de blé dur (Triticum turgidum L. var. durum) par le biais des marqueurs phénotypiques. J Appl Biosci 142 (1) : 14464-14477.

Kizilgeci F. 2019. Physiological, agronomical and quality response of bread wheat to phosphorus application under dryland condition. Appl Ecol Environ Res 17 (2): 1979-1987.

Kong L, Wang F, Feng B, Li S, Si J, Zhang B. 2010. The structural and photosynthetic characteristics of the exposed peduncle of wheat (Triticum aestivum L.): An important photosynthate source for grainfilling. BMC Plant Biol 10: 141. DOI: 10.1186/1471-2229-10-141

Ksouri R, Megdiche W, Debez A, Falleh H, Grignon C, Abdelly C. 2007. Salinity effects on polyphenol content and antioxidant activities in leaves of the halophyte Cakile maritima. Plant Physiol Biochem 45 (3-4): 244-249. DOI: 10.1016/j.plaphy.2007.02.001

Lichtenthaler HK. 1987. Chlorophylls and carotenoids: Pigments of photosynthetic biomembranes. Methods in Enzymology. Academic Press 148: 350-382. 
Lopes MS, Reynolds MP, Jalal-Kamali MR, Moussa M, Feltaous Y, Tahir ISA, Barma N, Vargas M, Mannes Y, Baum M. 2012. The yield correlations of selectable physiological traits in a population of advanced spring wheat lines grown in warm and drought environments. Field Crops Res 128: 129-136.

Mansouri A, Oudjehih B, Benbelkacem A, Fellahi Z, Bouzerzour H. 2018. Variation and relationships among agronomic traits in durum whea [Triticum turgidum L. Thell. ssp. turgidum conv. durum (Desf.) MacKey] under South Mediterranean growth conditions: Stepwise and path analyses. Intl J Agron. DOI: 10.1155/2018/8191749

Maury P, Langlade N, Grieu P, Rengel D, Sarrafi A, Debaeke P, Vincourt P. 2011. Ecophysiologie et génétique de la tolérance à la sécheresse chez le tournesol. Agron Innovations 14 :123-138.

Mazouz L, Bouzerzour H. 2017. Etude de la contribution des paramètres phéno-morphologiques dans la sélection du blé dur (Triticum durum Desf.) dans le climat semi-aride. Synthèse: Rev Sci Technol 35 (1) : 45-58.

Megherbi A, Mehdadi Z, Toumi F, Moueddene K, Bouadjra SEB. 2012. Tolérance à la sécheresse du blé dur (Triticum durum Desf.) et identification des paramètres morpho-physiologiques d'adaptation dans la région de Sidi Bel-Abbès (Algérie occidentale). Acta Bot Gall 159(1) : 137-143.

Mekhlouf A, Bouzerzour H, Bemahammed A, Hadj Sahraoui A, Harkati N. 2006. Adaptation des variétés de blé dur (Triticum dirum Desf.) au climat semi- aride. Sécheresse 17 (4): 507-513.

Melki M, Dahmane A. 2008. Identification de quelques mutants de blé dur performants en conditions de sécheresse naturelle. Sécheresse 19 (1) : 47-53.

Menad A, Meziani N, Bouzerzour H, Benmahammed A. 2011. Analyse de l'interaction génotype $\mathrm{x}$ milieux du rendement de l'orge (Hordeum vulgare L.): Application des modèles AMMI et la régression conjointe. Nat Technol 5: 99-106.

Merah O, Monneveux P. 2015. Contribution of different organs to grain filling in durum wheat under Mediterranean conditions I. contribution of post-anthesis photosynthesis and remobilization. J Agron Crop Sci 201 (5) : 344-352. DOI: $10.1111 /$ jac. 12109

Okamoto Y, Nguyen AT, Yoshioka M, Iehisa JC, Takumi S. 2013. Identification of quantitative trait loci controlling grain size and shape in the D genome of synthetic hexaploid wheat lines. Breed Sci 63 (4): 423-429.

ONFA. 2017. Pré-Bilan de la campagne céréalière 2016/2017. №2.

Rasheed A, Xia X, Ogbonnaya F, Mahmood T, Zhang Z, Mujeeb-Kazi A, He Z. 2014. Genome-wide association for grain morphology in synthetic hexaploid wheat using digital imaging analysis. BMC Plant Biol 14 (1) : 128. DOI: 10.1186/1471-2229-14-128

Rebetzke GJ, Bonnett DG, Reynolds MP. 2016. Awns reduce grain number to increase grain size and harvestable yield in irrigated and rainfed spring wheat. J Exp Bot 67 (9): 2573-2586. DOI: 10.1093/jxb/erw081

Sahri A, Chentoufi L, Arbaoui M, Muller M. H, Belqadi L, Birouk A 2014. Impact du relief et des circuits semenciers locaux sur la diversit $\tilde{\complement} \bigodot$ agro-morphologique du blÃ@ dur (Triticum turgidum ssp. durum) dans la vall $\tilde{A}(C)$ e dâ€ $€^{\mathrm{TM}}$ Er Rich â€"Imilchil (Maroc). Rev Marocaine Sci Agron Vet 2 (2)

Sallam A, Hamed E. S, Hashad M, Omara M. 2014. Inheritance of stem diameter and its relationship to heat and drought tolerance in wheat (Triticum aestivum L.). J Plant Breed Crop Sci 6 (1): 11-23.

Sallam A, Alqudah AM, Dawood MF, Baenziger PS, Börner A. 2019. Drought stress tolerance in wheat and barley: Advances in physiology, breeding and genetics research. Intl J Mol Sci 20 (13) 3137. DOI: 10.3390/ijms20133137

Salmi M. 2015. Caractérisation morpho-physiologique et biochimique de quelques générations F2 de blé dur (triticum durum desf.) sous conditions semi-arides. [Thèse]. Université Ferhat Abbas, Sétif. [Algérie]

Salmi M, Haddad L, Oulmi A, Benmahammed A, Benbelkacem A. 2015. Variabilité phénotypique et sélection des caractères agronomiques du blé dur (Triticum durum Desf.) sous conditions semi-arides. Eur Sci J 11 (21): 99-111.

Safarova G, Akhundova E, Ramazanova M, Salayeva S, Ojaghi J. 2019. Agro-morphological characterization of Azerbaijan durum wheat accessions by multiple statistical analysis. Khazar J Sci Technol 3 (1): $5-13$.

Samira IB, Dridi-Mouhandes B, ben Mansour-Gueddes S, Denden M. 2012. 24-Epibrassinolide ameliorates the adverse effect of salt stress $(\mathrm{NaCl})$ on pepper (Capsicum annuum L.). J Stress Physiol Biochem 8 (1) :232-240.

Sanchez-Garcia M, Álvaro F, Martín-Sánchez J.A, Sillero J.C, Escribano J, Royo C. 2012. Breeding effects on the genotypex environment interaction for yield of bread wheat grown in Spain during the 20th century. Field Crops Res 126: 79-86.

Sang D, Chen D, Liu G, Liang Y, Huang L, Meng X, Chu J, Sun X, Dong G, Yuan Y, Qian Q, Li J, Wang Y. 2014. Strigolactones regulate rice tiller angle by attenuating shoot gravitropism through inhibiting auxin biosynthesis. Proc Natl Acad Sci 111 (30): 11199-11204.

Sassi K, Abid G, Jemni L, Dridi-Al Mohandes B, Boubaker M. 2012. Etude comparative de six variétés de blé dur (Triticum durum Desf.) vis-à-vis du stress hydrique. J Anim Plant Sci 15: 2157-2170.

Semcheddine N, Oulmi A, Rouabhi A, Hafsi M. 2017. Relationship between grain yield, agronomic traits and carbon isotope discrimination in durum wheat cultivated under semi-arid climate. Intl Innovation Appl Stud 20: 1068-1077.

Simonneau T, Ollat N, Pellegrino A, Lebon E. 2014. Contrôle de l'état hydrique dans la plante et réponses physiologiques de la vigne à la contrainte hydrique. Agron Innovations 38: 13-32.

Slafer GA, Araus JL, Royo C, Del Moral LFG. 2005. Promising eco-physiological traits for genetic improvement of cereal yields in Mediterranean environments. Ann Appl Biol 146 (1): 61-70.

Subhashchandra B, Lohithaswa HC, Desai SA, Hanchinal RR, Kalappanavar IK, Math KK, Salimath PM. 2009. Assessment of genetic variability and relationship between genetic diversity and transgressive segregation in tetraploid wheat. Karnataka J Agric Sci 22 (1): 36-38

Toumi M, Barris S, Aid F. 2014. Effects of water and osmotic stress on the accumulation of proline and malondialdehyde (MDA) in two varieties of colza (Brassica napus L.). Bul Sci Inst: Life Sci Sect 36: 17-24.

Troll W, Lindsley J. 1955. A photometric method for the determination of proline. J Biol Chem 215 (2): 655-660.

Whan AP, Smith AB, Cavanagh CR, Ral JPF, Shaw LM, Howitt CA, Bischof L. 2014. Grain Scan: A low-cost, fast method for grain size and color measurements. Plant Methods 10 (1): 23

Xynias IN, Mylonas I, Korpetis EG, Ninou E, Tsaballa A, Avdikos ID, Mavromatis AG. 2020. Durum wheat breeding in the Mediterranean region: Current status and future prospects. Agronomy 10 (3): 432. DOI: 10.3390/agronomy10030432

Zarkti H, Ouabbou H, Udupa S. M, Gaboun F, Hilali A. 2012. Agromorphological variability in durum wheat landraces of Morocco. Aust J Crop Sci 6: 1172 .

Zerafa C, Ghenai A, Benlaribi M. 2017. Comportement Phénologique et Morpho-Physiologique de Quelques Génotypes d'orge et de blé. Eur Sci J 13 (6): 287-299.

Zoghmar M, Kara Y, Farhati L, Zeltni A.E, Bouchareb R. 2016. Morphological and agricultural diversity of durum wheat varieties sown in a semi-arid area. Adv Environ Biol 10 (4): 108- 120 